\title{
Wykorzystanie klasycznego defektoskopu ultradźwiękowego do oceny połączeń zgrzewanych blach karoseryjnych
}

\author{
The use of classical ultrasonic flaw detector \\ to evaluation of resistance spot welds \\ of car body sheet
}

\section{Streszczenie}

W pracy przedstawiono problematykę wykorzystania klasycznego defektoskopu ultradźwiękowego do badania i oceny połączeń zgrzewanych, wykorzystywanych w konstrukcji współczesnych pojazdów samochodowych. Ze względu na to, że same metody badania tych połączeń są znane, w pracy ograniczono się do oszacowania możliwości uzyskania impulsów ultradźwiękowych, zobrazowanych na ekranie defektoskopów, przydatnych do oceny połączeń podczas ich badań. Badania wykonano dwoma różnymi defektoskopami - przeznaczonym do badania połączeń zgrzewanych i uniwersalnym. Wykonane pomiary pokazały, że jest możliwe badanie defektoskopem klasycznym połączeń zgrzewanych, jednakże w sytuacji prowadzenia częstych kontroli (np. w produkcji seryjnej) uzasadnione jest posiadanie defektoskopu sepcjalistycznego.

Słowa kluczowe: ultradźwięki, złącza zgrzewane, defektoskop ultradźwiękowy, NDT

\begin{abstract}
The paper presents the problem of use of classical ultrasonic flaw detector for testing and evaluation of welded joints which are used in the construction of modern motor vehicles. Due to the fact that methods to test the connections are known, this work is limited to the possibility of obtaining valid flaw signal on the screen of ultrasonic flaw detector research. The tests were performed with two different flaw detectors - one dedicated to the study inseparable connection and second - the classic flaw detector. The measurements had shown that it is possible to study welded joints by classic flaw detector, however, in case of conduct frequent inspections (eg. in mass production) is justified to buy dedicated flaw detector.
\end{abstract}

Keywords: ultrasound, resistance spot weld, ultrasonic flaw detector, NDT

Dr inż. Jakub Kowalczyk; mgr inż. Dariusz Ulbrich; dr hab. inż. Marian Jósko, prof. PP - Politechnika Poznańska, Instytut Maszyn Roboczych i Pojazdów Samochodowych. 


\section{Wstęp}

W budowie karoserii oraz innych elementów konstrukcyjnych współczesnych pojazdów samochodowych wykorzystuje się znaczną ilość połączeń zgrzewanych [1,2]. Ze względu na wpływ jakości tych połączeń na funkcjonalność i bezpieczeństwo konstrukcji niezwykle ważna jest kontrola jakości ich wykonania. Producenci pojazdów powszechnie stosują kontrolę niszczącą, polegającą na rozerwaniu połączeń i późniejszą ich ocenę jakościowo-ilościową. Część z kontrolowanych połączeń jest przecinana, szlifowana a następnie wykonuje się analizę mikroskopową połączenia. W dużych zakładach produkcyjnych coraz częściej prowadzi się badania nieniszczące, które uzupełniają, a nawet - w określonych przypadkach - zastępują badania niszczące. Do takich badań wykorzystuje się np. aparaturę ultradźwiękową, która umożliwia nieniszczącą kontrolę połą-

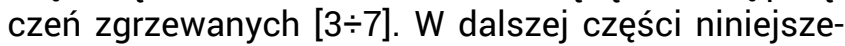
go artykułu skupiono się wyłącznie na połączeniach zgrzewanych.

Zasadniczym celem pracy jest określenie możliwości zastosowania klasycznego cyfrowego defektoskopu ultradźwiękowego, w szczególności do badania połączeń zgrzewanych, stosowanych w budowie karoserii pojazdów samochodowych. Wykorzystanie takiego defektoskopu zostanie odniesione do sprawdzonego już w warunkach przemysłowych defektoskopu specjalistycznego, z oprogramowaniem przeznaczonym do wykonywania przedstawionych badań.

Autorzy zajmują się zastosowaniem badań nieniszczących do oceny jakości połączeń nierozłącznych. Do badań wybrano defektoskop USM 35XS firmy Krautkramer. Wybór tego defektoskopu jest uzasadniony jego częstym stosowaniem w przemysłowych laboratoriach kontroli jakości. Defektoskop ten jest powszechnie wykorzystywany do wykrywania wad materiałowych, kontroli jakości połączeń spawanych oraz pomiarów grubości. W klasycznych badaniach ultradźwiękowych bada się elementy o grubości powyżej $6 \mathrm{~mm}$, a w przypadku połączeń spawanych - powyżej $8 \mathrm{~mm}$. Elementy zgrzewane w konstrukcji pojazdów samochodowych, niejednokrotnie mają grubość poniżej $1 \mathrm{~mm}$, a zdarzają się elementy wykonywane $z$ blach o grubości $0,6 \mathrm{~mm}$. Wymusza to wykorzystanie specjalistycznych głowic ultradźwiękowych. W badaniach połączeń zgrzewanych wykorzystuje się zatem głowice ultradźwiękowe o wysokiej częstotliwości, wynoszącej niejednokrotnie $20 \mathrm{MHz}$. Zasadniczo znane są metody badania jakości połączeń zgrzewanych metodą ultradźwiękową, z tego powodu w dalszej części pracy skoncentrowano się nie na samych sposobach prowadzenia badań, lecz na możliwościach uzyskania prawidłowych, przydatnych układów obrazów impulsów ultradźwiękowych na ekranie defektoskopu.

\section{Aparatura do badania połączeń zgrzewanych}

Uznani producenci aparatury ultradźwiękowej posiadają w swojej ofercie specjalistyczne stanowiska do badania połączeń zgrzewanych. Zalety takich stanowisk, to - przede wszystkim - możliwość samodzielnego tworzenia przez użytkownika programów kontrolnych, krótki czas potrzebny do wyszkolenia personelu badań nieniszczących oraz dedykowane oprogramowanie, umożliwiające automatyczną analizę wyników. W wyniku tych rozwiązań pracownik bezpośrednio prowadzący kontrolę jedynie wybiera odpowiednią głowicę według wskazań programu i przykłada ją do badanej zgrzeiny. Przykładowy, defektoskop, umożliwiający ultradźwiękową ocenę połączeń zgrzewanych, przedstawiono na rysunku 1.

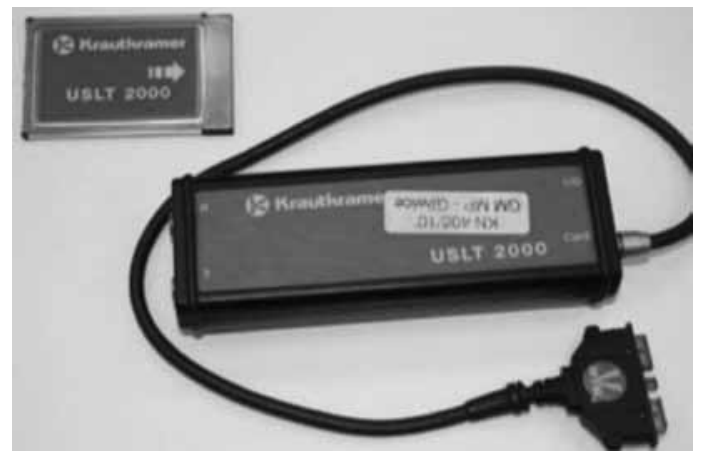

Rys. 1. Defektoskop do badania połączeń zgrzewanych Fig. 1. View of flaw detector for testing welded joints

Koszt takiej aparatury jest jednak relatywnie wysoki, stanowiący barierę dla małych firm, zajmujących się produkcją, naprawą lub regeneracją, a wykorzystujących w swoich technologiach zgrzewanie. Część firm posiada już na wyposażeniu laboratorium klasyczną aparaturę ultradźwiękową.

Jako alternatywę dla przedstawionego stanowiska można zaproponować defektoskop USM35. Jest to klasyczny defektoskop ultradźwiękowy, przedstawiony na rysunku 2.

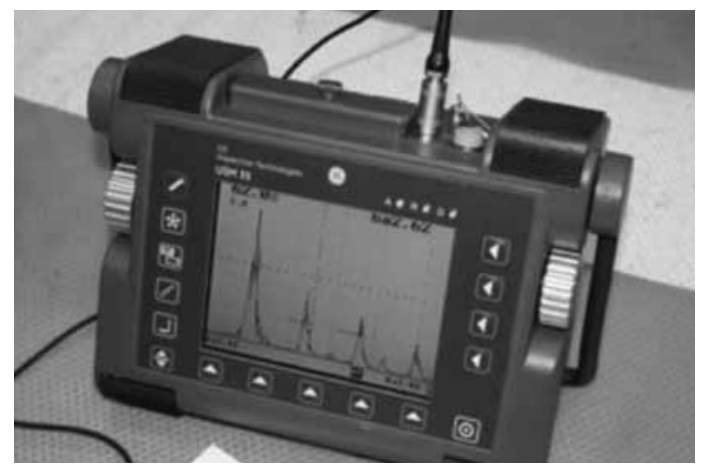

Rys. 2. Klasyczny defektoskop ultradźwiękowy - widoczny układ impulsów uzyskany z obszaru połączenia

Fig. 2. Classic ultrasonic flaw detector during welded joint inspection 
Jednym z najważniejszych elementów, wchodzących w skład stanowisk do ultradźwiękowych badań połączeń zgrzewanych, jest głowica ultradźwiękowa. Ze względu na niewielką grubość badanych elementów powinna być to głowica o wysokiej częstotliwości. Producenci aparatury do badań ultradźwiękowych zaproponowali - w takim przypadku - głowicę o częstotliwości $20 \mathrm{MHz}$. Dodatkowo powinna być to głowica z linią opóźniającą, pozwalającą na prowadzenie pomiarów poza obszarem pola bliskiego. W praktyce wykorzystuje się głowice z wodną linią opóźniającą oraz z linią opóźniająca realizowaną za pomocą odpowiednio obrobionego tworzywa. Ze względu na charakter badań, w szczególności kształt badanej powierzchni w przypadku zgrzeiny, w dalszych badań postanowiono wykorzystać głowicę z wodną linią opóźniającą. Przykładową głowicę, wykorzystywaną w badaniach połączeń zgrzewanych, przedstawiono na rysunku 3.

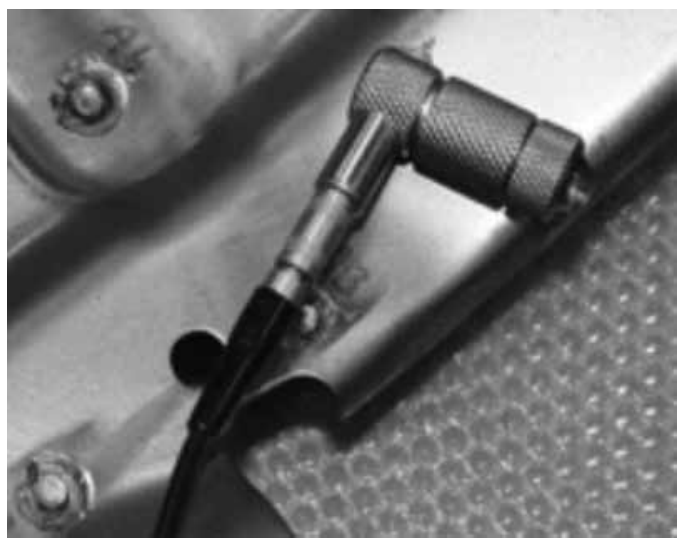

Rys. 3. Głowica ultradźwiękowa wykorzystywana do badania połączeń zgrzewanych

Fig. 3. Ultrasonic transducer used to welded joint inspection

\section{Badania połączeń zgrzewanych}

Do badań połączeń zgrzewanych używa się różnych miar ich ultradźwiękowej oceny. W przypadku połączeń adhezyjnych wykorzystuje się np. moduł ciśnieniowego współczynnika odbicia, a w przypadku połączeń zgrzewanych analizowany jest układ uzyskiwanych impulsów, zobrazowanych na ekranie defektoskopu ultradźwiękowego. O jakości połączenia zgrzewanego może świadczyć np. liczba impulsów fali ultradźwiękowej odbitej od dna zgrzeiny lub od dna pierwszej z łączonych blach. Dla przedstawianych połączeń ultradźwiękowe miary ich jakości opierają się na weryfikacji układu obrazów impulsów na ekranie defektoskopu.

W celu sprawdzenia, na ile klasyczny defektoskop ultradźwiękowy umożliwia kontrolę połączeń zgrzewanych, wykonano szereg pomiarów wybranych połączeń, zarówno defektoskopem specjalnym, jak i klasycznym. W czasie badań rejestrowano uzyskiwane na ekranach aparatury obrazy impulsów ultradźwiękowych. Wykonano pomiary w miejscach, w których zgrzeina została wykonana prawidłowo - była wysokiej jakości, oraz dla zgrzein, w których jądro było za małe. Obraz uzyskany na ekranie defektoskopu specjalnego w czasie pomiarów zgrzeiny wysokiej jakości, przedstawiono na rysunku 4, natomiast obraz uzyskiwany w czasie pomiarów w miejscu, w którym stwierdzono brak połączenia - na rysunku 5.

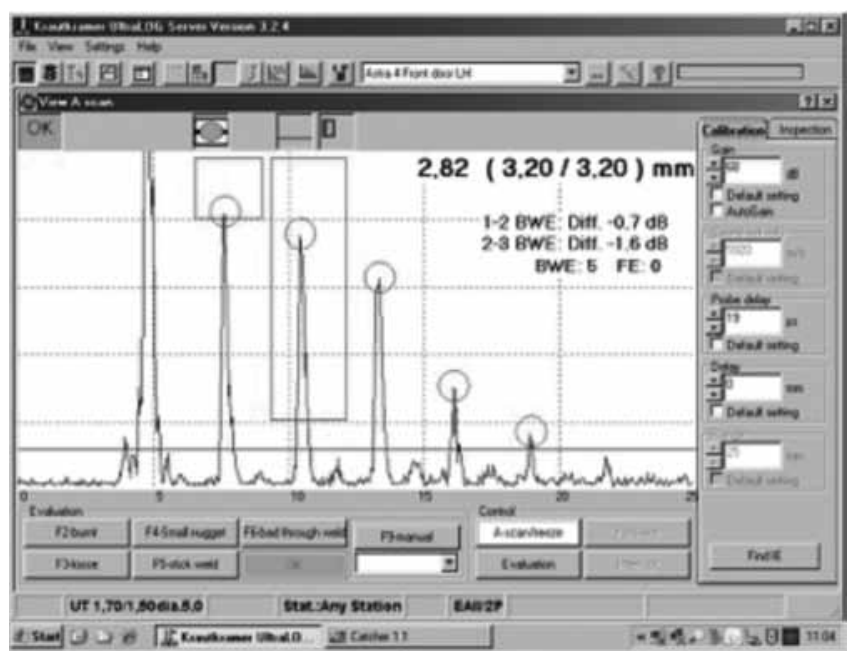

Rys. 4. Widok ekranu defektoskopu przemysłowego podczas badania prawidłowo wykonanego połączenia zgrzewanego

Fig. 4. View of industrial flaw detector screen during the test performed on a good welded joint

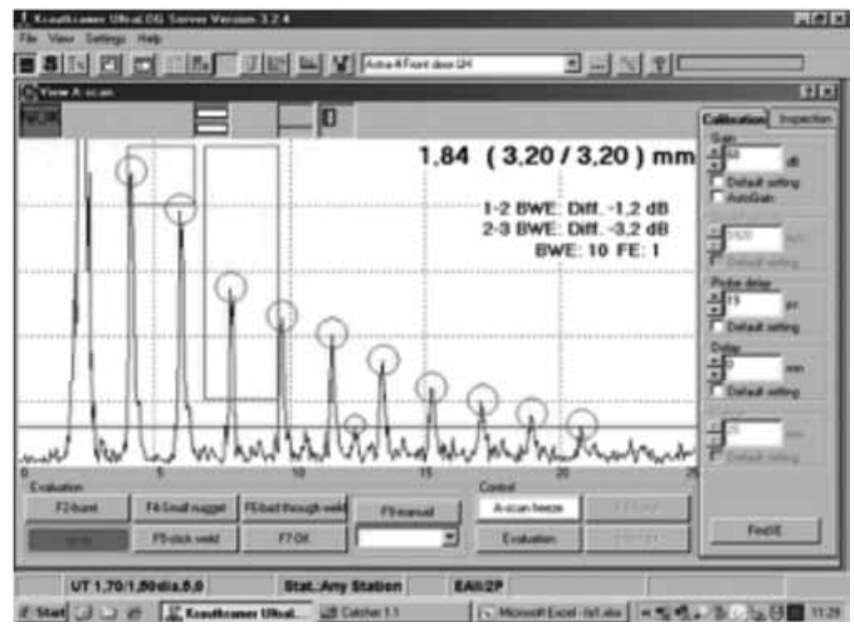

Rys. 5. Widok ekranu defektoskopu przemysłowego podczas badania wadliwie wykonanego połączenia zgrzewanego

Fig. 5. View of industrial flaw detector screen during the test performed on a bad welded joint

W celu porównania obrazów impulsów fal ultradźwiękowych, pokazanych na rysunkach 4 i 5, na rys. 6 przedstawiono obraz uzyskany podczas badania zgrzeiny defektoskopem klasycznym, na którym wyraźnie widać obraz impulsów fali odbitej od dna połączenia zgrzewanego.

W przypadku wykorzystywania do oceny jakościpołączenia zgrzewanego defektoskopu dedykowanego, pracownicy kontroli jakości mogą interpretować jego 
wyniki praktycznie on-line. Niejednokrotnie interpretacja wyników badań sprowadza się do obserwacji pola, w którym wyświetlane jest oznaczenie połączenia dobrego (kolor zielony) i błędnego (kolor czerwony). Natychmiast po uzyskaniu wyniku pomiarów na ekranie defektoskopu automatycznie zostają podane spadki decybelowe między wybranymi obrazami impulsów, liczba impulsów, grubość badanego elementu, również w odniesieniu do grubości wzorcowej. Pozwala to na niezwłoczne podjęcie decyzji o jakości połączenia zgrzewanego. Nie bez znaczenia jest fakt, że po uprzednim zaprogramowaniu defektoskopu pracownik działu kontroli jakości ma zobrazowane na ekranie miejsce przyłożenia wskazanej głowicy. W przypadku defektoskopu klasycznego uzyskiwany obraz impulsów fali ultradźwiękowej należy każdorazowo analizować, co wymaga lepszego przygotowania personelu oraz dłuższego czasu dla prawidłowej analizy. Jednym z największych problemów stwierdzonych podczas prowadzenia badań ultradźwiękowym defektoskopem klasycznym jest konieczność ciągłych zmian nastaw, np. początku obserwacji, co wynika z uginania się membrany głowicy ultradźwiękowej. W przypadku stanowiska dedykowanego proces ten jest zautomatyzowany.

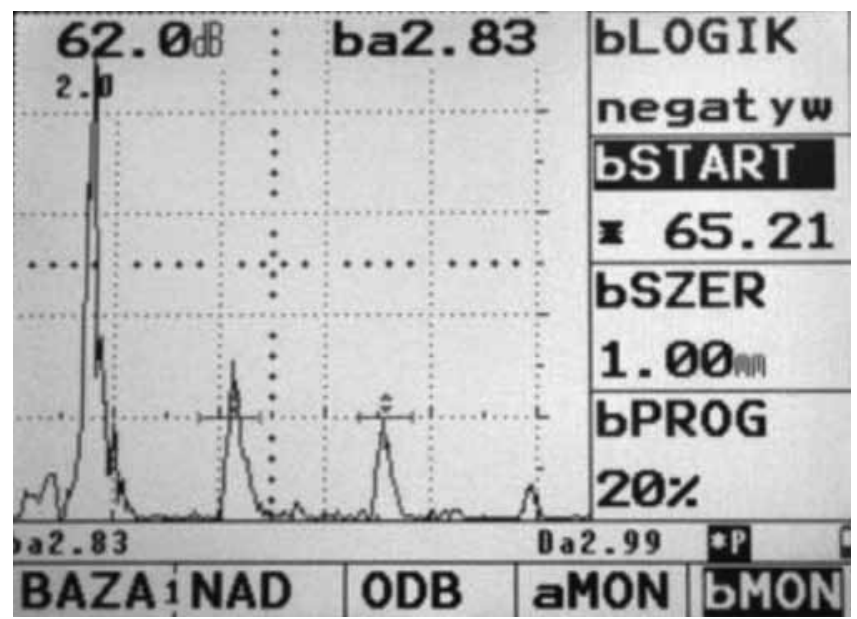

Rys. 6. Widok defektoskopu klasycznego w czasie badania prawidłowo wykonanego połączenia zgrzewanego

Fig. 6. View of the classic flaw detector screen during the test performed on good welded joint

\section{Podsumowanie}

W określonych warunkach klasyczny defektoskop ultradźwiękowy może być wykorzystywany do badania połączeń zgrzewanych. Ograniczenie wykorzystania klasycznego defektoskopu ultradźwiękowego nie wynika z fizycznych możliwości uzyskania przydatnych na potrzeby badań obrazów impulsów fali ultradźwiękowej, lecz w głównej mierze z ergonomii obsługi i możliwości automatyzacji prowadzonych badań, wpływających na ich czasochłonność. Badania połączeń zgrzewanych, prowadzone defektoskopem klasycznym, wymagają pracy w zespole dwuosobowym. W przypadku badań rozpoznawczych i pilotażowych uzasadnione jest prowadzenie prac z wykorzystaniem defektoskopu klasycznego. W przypadku badań przemysłowych (podczas produkcji), szczególnie w sytuacji ich dużej liczby, zdecydowanie korzystniej jest stosować defektoskop ultradźwiękowy, dedykowany do badań połączeń zgrzewanych.

\section{Literatura}

[1] Słania J., Kuk Ł.: Proces łączenia materiałów do budowy pojazdów i nadwozi w przemyśle samochodowym, Przegląd Spawalnictwa, nr 3, 2014.

[2] Godek J., Senkara J.: Metodyka badań trwałości elektrod do zgrzewania oporowego punktowego z wykorzystaniem zmechanizowanego stanowiska pomiarowego, Przegląd Spawalnictwa, nr 6, 2014.

[3] Kowalczyk J., Ulbrich D., Mańczak R.: Badanie połączeń zgrzewanych blach stalowych metodą ultradźwiękową, Przegląd Spawalnictwa, nr 6, 2014.

[4] Kaminski R.: Ultrasonic Testing of Spot Welded Joints on Coated Steel Sheets and Optimization of Welding Parameters. Krautkramer. Spotweldtesting.com, 20.10.2013.
[5] Buckley J., Servent R.: Improvements in Ultrasonic Inspection of Resistance Spot Welds. The 2nd International Conference on Technical Inspection and NDT (TINDT 2008). October 2008, Tehran, Iran.

[6] Vural M., Akkus A.: The Ultrasonic Testing of the Spot WeIded Different Steel Sheets. Journal of Achievements in Materials and Manufacturing Engineering. Vol. 18, September - October 2006.

[7] Maev R., Chertov A., Regalado W., Karloff A., Lichaa P., Phan T.: Real Time Ultrasonic System for Resistance Spot Weld Inspection. Integration in Assembly Line. 4th International Candu In-service inspection and NDT in Canada. 18-21 June 2012, Toronto, Canada. 